
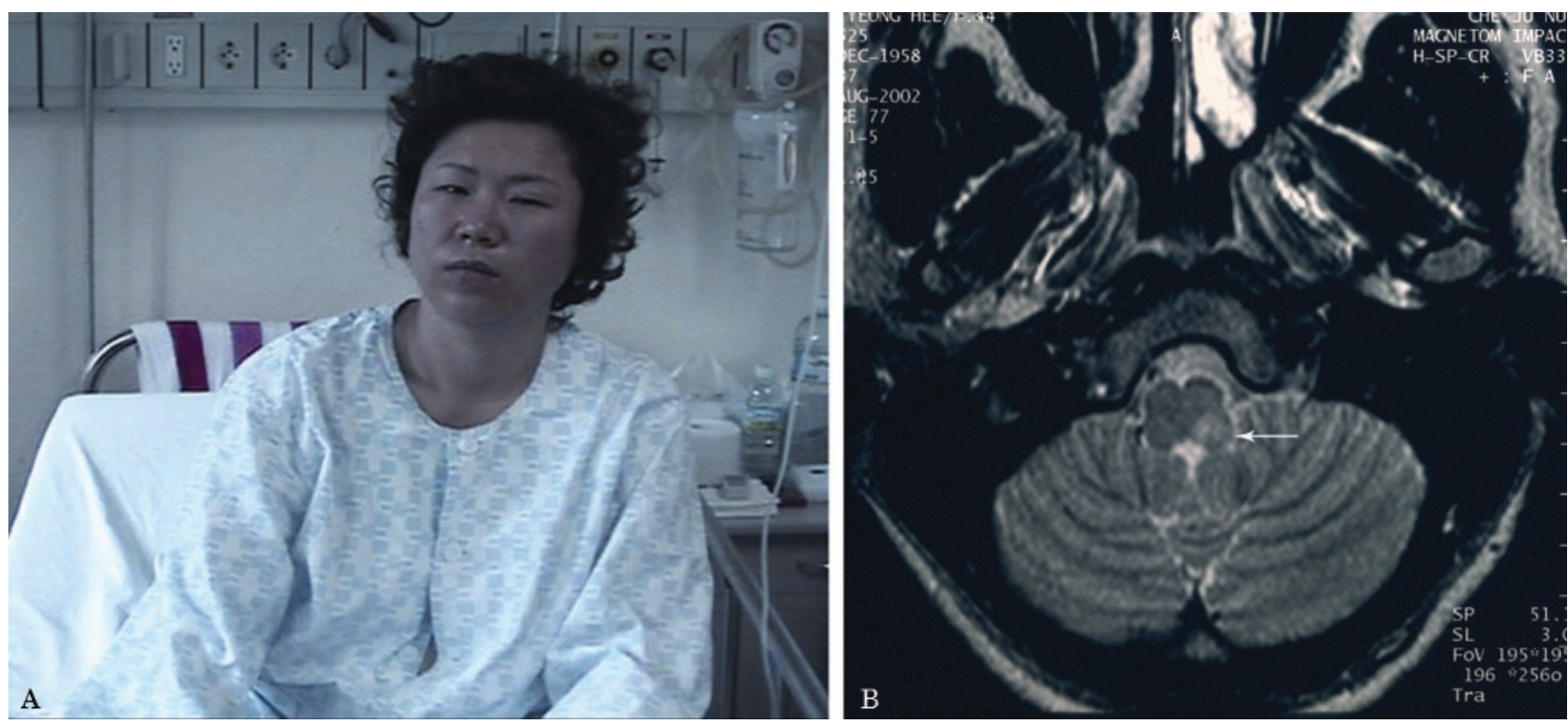

Figure. (A) Patient shows leftward truncal lateropulsion and left Horner syndrome. (B) T2-weighted MRI demonstrates acute infarction in the left dorsolateral medulla (arrow).

\section{VIDEo Ocular lateropulsion in Wallenberg syndrome}

J.S. Kim, MD, S.Y. Moon, MD, S.-H. Park, MD, B.-W. Yoon, MD, and J.-K. Roh, MD, Seoul, Korea

A 44-year-old woman presented with vertigo that had developed after neck massage. She showed direction-changing nystag-

Additional material related to this article can be found on the Neurology Web site. Go to www.neurology.org and scroll down the Table of Contents for the June 22 issue to find the title link for this article.

Address correspondence and reprint requests to Dr. Ji Soo Kim, Department of Neurology, Seoul National University Bundang Hospital, 300 Gumi-dong, Bundang-gu, Seongnam-si, Gyeonggi-do, 463-707, Korea; email: jisookim@snu.ac.kr mus, left Horner syndrome, and decreased pain and temperature sensation in the left face and right side of the body. Ocular and truncal lateropulsion to the left was evident (figure, A; see video at www.neurology.org). MRI revealed infarction in the left dorsolateral medulla (figure, B).

Ocular lateropulsion refers to ocular motor bias toward (ipsipulsion) or away from (contrapulsion) the lesion side without limitation of eye motion..$^{1,2}$ It comprises steady-state ocular deviation, asymmetric horizontal saccades, and oblique misdirection of vertical saccades. Ocular ipsipulsion in Wallenberg syndrome has been ascribed to damage to the climbing fibers from the contralesional inferior olivary nucleus to the dorsal vermis.

1. Baloh RW, Yee RD, Honrubia V. Eye movements in patients with Wallenberg's syndrome. Ann NY Acad Sci 1981;374:600-613.

2. Ranalli PJ, Sharpe JA. Contrapulsion of saccades and ipsilateral ataxia: a unilateral disorder of the rostral cerebellum. Ann Neurol 1986;20:311-316. 


\section{Neurology}

\section{Ocular lateropulsion in Wallenberg syndrome}

J. S. Kim, S. Y. Moon, S. -H. Park, et al.

Neurology 2004;62;2287

DOI 10.1212/WNL.62.12.2287

\section{This information is current as of June 21, 2004}

\section{Updated Information \& Services}

\section{Supplementary Material}

\section{References}

\section{Subspecialty Collections}

Permissions \& Licensing

Reprints including high resolution figures, can be found at: http://n.neurology.org/content/62/12/2287.full

Supplementary material can be found at: http://n.neurology.org/content/suppl/2004/06/05/62.12.2287.DC1

This article cites 2 articles, 0 of which you can access for free at: http://n.neurology.org/content/62/12/2287.full\#ref-list-1

This article, along with others on similar topics, appears in the following collection(s):

\section{All Cerebrovascular disease/Stroke}

http://n.neurology.org/cgi/collection/all_cerebrovascular_disease_strok e

All Neuro-ophthalmology

http://n.neurology.org/cgi/collection/all_neuroophthalmology

\section{Infarction}

http://n.neurology.org/cgi/collection/infarction

MRI

http://n.neurology.org/cgi/collection/mri

Ocular motility

http://n.neurology.org/cgi/collection/ocular_motility

Information about reproducing this article in parts (figures,tables) or in its entirety can be found online at:

http://www.neurology.org/about/about_the_journal\#permissions

Information about ordering reprints can be found online:

http://n.neurology.org/subscribers/advertise

Neurology ${ }^{\circledR}$ is the official journal of the American Academy of Neurology. Published continuously since 1951, it is now a weekly with 48 issues per year. Copyright . All rights reserved. Print ISSN: 0028-3878. Online ISSN: 1526-632X.

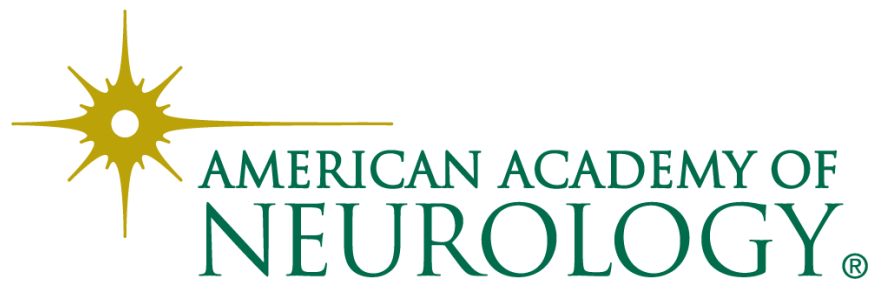

